\title{
Improve Cognitive and Speaking Ability Through the Use of Manipulatives Media "Life Cycle of a Butterfly" for the Kindergarten Children In Group B
}

\author{
Epritha Kurniawati, Linda Dwiyanti \\ Universitas Nusantara PGRI Kediri, Indonesia \\ Corresponding e-mail: itha2311@gmail.com
}

\begin{abstract}
Early childhood education for children Kindergarten group B are in the age range of 5-6 years with the golden age period is very sensitive to any stimulus from outside, so that the maximum stimulation will be very big influence on children's development, especially on cognitive development and Speaking.Early childhood can only learn concrete things, because at this stage they can not abstract thinking, so it takes a learning media to help learning. This study aimed to describe (1) improvement of cognitive and Speaking ability of Early childhood (AUD) through the use of media manipulative "Life Cycle of the Butterfly" for children in TK group B, (2) increasing proficiency AUD through the use of media manipulative "Life Cycle of a Butterfly" for children in TK group B, (3) increased activity of children in learning cognitive skills and Speaking development for children in TK group B. Research type used is classroom action research with the collaboration of Arikunto Suharsimi cycle models. Each cycle consists of planning, action, observation, and reflection. Technique of collecting data used observation method and documentation and research instruments using observation sheet abilities of children and child activity observation sheet. The results of data analysis showed an increase in cognitive abilities on cycle I gained an average of $60 \%$ and on cycle II increased Being averaged $82 \%$. While at the cycle speaking skills I gained an average of $57 \%$ and cycle II increased Being averaged $84 \%$, so no to need to be improved Again Into the next cycle. Thus, it can be concluded that through the media manipulative "Life Cycle of a Butterfly" can improve cognitive abilities and speaking to the children in group B
\end{abstract}

Keywords: Butterfly, Cognitive and Speaking, Media

\section{INTRODUCTION}

Education is an effort made to educate the nation's children in order to achieve advanced life through the realization of a conducive learning atmosphere, learning activities interesting and enlightening, as well as the process of creative education. Child during early childhood is the people who continue to process development by leaps and bounds, which is a decisive period in the course of the next. Early childhood education, or known as ECD has become an important part of life, because in early childhood is given a wide range of learning that is intended to develop all aspects of child development

In connection with this fact, the education in kindergarten is expected to develop and facilitate the potential of each students. Learning in kindergarten can be done in various ways, namely: through seeing, hearing, talking, interacting, reflect, and very precise use play activities and games.

Based on cognitive development phase being addressed by Piaget, the child was in a preoperational phase. In this phase, the symbolic function of children is growing rapidly. Symbolic functions related to the child's ability to visualize objects to challenge something or in other objects mentally, or without the presence of object or objects in concrete. Therefore, children Speaking development in this phase is explained by the symbolic function. Therefore education should be facilitating the child through activities that provide opportunities for children feel happy to recognize and identify objects that were surrounding 
environment educators also need to direct and provide workflow and clues that are simple.

Based on observations conducted in kindergarten group B show that: First, the child is less able to accept the concept of the introduction of science simply because teachers only explain orally and using media Poster is not a concrete object that can be seen and held the child so the cognitive ability particularly cognitive science underdeveloped child maximum. Secondly, so it also affects the ability to speak, when the teacher asked about what has been described children tend to be quiet and when the teacher asked the children to come forward to explain again about the life cycle of butterflies, children are less able to express because it is less maximal accepted concept child so that the child is also difficult to retell, and teachers also rare to train children to retell what they have seen and notice.

Third, because of the instructional media used by the teacher during the learning process less varied or monotonous so that children feel the saturation and finally opted for a crowded own and do not focus on participating in learning activities, media teachers use every day are less effective and innovate because teachers tend to use Student worksheet and pictures plastered on the wall so that the class of less foster child's interest in terms of curiosity and interaction between educators and students so that children tend to be passive. Fourth, then in the end of the activities of educators not provide a reinforcement and encourage interaction between children with frequently asked questions about the activities that have been carried out during the day and less give reward for children who can complete the task well and behaved well during the learning process.

In learning activities, especially in kindergarten media presence is important that can be as an intermediary to deliver instructional materials that will be done in the learning activities, the media can also help represent what the material described teacher through words or sentences, even abstractness materials can be concretized by the presence of media. Instructional media used must be able to attract the attention of students in learning activities and further stimulate children's learning activities. There are various kinds of media that can be used by teachers in learning activities one of which is the manipulative media. Media manipulative is a creative media created by educators as a means of delivering information when the learning process, the media is the result of the educators in manipulating objects or targets are evident in the form of a model that is a real picture of the object in $3 \mathrm{D}$ visualized realistically resemble the actual situation according to Nana and Ahmad (2010: 9).
In principle of early childhood, child learning to think through the concrete object, in this concept of children should be learning with real objects so that children do not wander or confused. Children prefer to remember an object that can be seen, held more lasting and acceptable by the brain in sensation and memory, according Yuliani (2009: 93). Of course, the media used to be able to stimulate the child to want to learn without coercion or feeling depressed in the learning process. Thus, the inclusion of knowledge received by the children will be more meaningful and the child's ability to understand the concept will also increase. Therefore, one medium that can be used in the introduction of a simple science. to improve cognitive and Speaking abilities manipulative media that "Life Cycle of the Butterfly" by utilizing existing materials surrounding environment. Media aims to provide knowledge to the children that the names of the animals are often found around the home environment (egg, caterpillar, chrysalis, butterfly), process development or life cycle of butterflies starting from the egg then becomes a caterpillar and pupae and then into butterflies beautiful butterfly, but it also attracted the attention of students, to be more focused when following learning, and students can also directly use the media to explain and tell to describe what has been explained by educators appropriate cognitive and Speaking abilities of children naturally.

This study aimed to describe (1) the increase in cognitive abilities through the use of media manipulative "Life Cycle of the Butterfly" children in kindergarten group B, (2) improving Speaking skills through the use of media manipulative "Life Cycle of the Butterfly" children in kindergarten group B, (3) the activities of children in learning cognitive skills and Speaking development of media use manipulatives "Life Cycle of the butterfly". Based on the explanation above, to improve cognitive skills and Speaking, by using manipulative media "Life Cycle of the Butterfly" for children in kindergarten group B ".

\section{LITERATURE REVIEW}

\subsection{Meaning Early Childhood Education}

Early childhood is a child in the age range of 0-8 years, according to experts the education of children. According to Mansur (2005: 88 ) early childhood is a group of children who are in the process of growth and development that is unique.

Early Childhood Education (ECD) is a form of organization of education that focuses on laying the foundation toward growth and physical development 
(coordination of fine and coarse), intellect (the intellect, creativity, emotional intelligence, spiritual), social, emotional, language, according to the uniqueness and the developmental stages through which (Jawati: 2013)

\subsection{Early Childhood Cognitive Ability}

Cognitive is a process of thinking, the ability of individuals to connect, assess, and consider an incident or event according to Susanto (2011: 47). An expert named Gagne (in Jamaris, 1976: 71) describes "is a cognitive process that occurs internally within the central nervous system at the time of human thinking. Cognitive development is growing gradually, in line with the development of physical and nerves of the central nervous system ".

\subsection{Meaning of Early Childhood Speaking Ability}

Language Has four aspects of language skills, i.e. listening skills, speaking, reading and writing. every aspect

skill is closely related to the three aspects other skills. language skills are obtained through a relationship regularly, namely: the childhood learning listening to the language, and then speak, after that learn to read and write. Speaking as one of the aspects of skills language that develops in a child's life, generally means a delivery mean (ideas, thoughts, ideas, or hearts) one person to another by using spoken language so that such purposes can understood by others (Department of Education in Suhartono, 2005: 20).

Vocabulary is the basis of phonological sensitivity, which is the key of development language that supports reading (Dickinson, et al: 2003).

\subsection{Meaning of Media}

Media said as all forms and channels used to distribute the messages / information. Said all make sense that the so-called media is not limited to the type of media that is designed specifically to achieve certain goals, but also the existence of which can be used to clarify or facilitate students' understanding of the material, or a specific message. So, any shape if it can be used to distribute messages can be called media. Concern with learning, the media is anything that can be used to convey messages from the sender to the receiver so that it can stimulate thoughts, feelings and concerns of the students to achieve educational goals. Heinich and Russell (2005) defines the media as a communication channel. Medium term itself comes from Latin and is the plural form of the word "medium" which literally means "intermediary" is an intermediary source of the message (a source) to the message receiver (a receiver).

Educators variety of instructional media and teaching format available to present information. Selecting a medium that motivates learners is an important ( Rodgers : 2005).

\subsection{Design of Making Learning Media}

Name of Media: Media Manipulations "Life Cycle of the Butterfly"

Media manipulative is a creative media that were created by teachers as a means of delivering information when the learning process, the media is the result of teachers in manipulating objects or targets are evident in the form of a model in the opinion of Nana and Ahmad (2010: 9) is a real picture of objects in 3D are visualized realistically resemble the real state of the egg, caterpillar, chrysalis and butterfly.

Teachers make manipulative media "Life Cycle of the Butterfly" so that children know and learn about the animals living creature that is often look surrounding environment. Media aims to attract the attention of students, to be more focused when following learning, and students can also immediately see concrete objects are manipulated and also children can use the media to reveal what has been described by teachers according to cognitive ability and Speaking of children natural.

Them/ Subtheme: Animal/Butterfly

Capabilities developed:

a. Cognitive: the child is able to mention the random sequence and animal names in the "Life Cycle of Butterflies" sequence from egg-caterpillar-chrysalis-butterfly, children are able to sort objects, unable to explain back

b. Speaking: Children listening to the teacher, the child is able to focus, the child is able to answer questions, the child is able to retell the life cycle process

\section{METHODOLOGICAL}

\subsection{Research Design}

The study was designed using the design of classroom action research (CAR), which is a form of research to undertake corrective measures in order to 
improve or enhance classroom practice more professionally.

CAR be gradual and cyclical, in order to determine the increase in the ability of all children in one class rather than individuals. CAR is done collaboratively, which is the core of teachers as implementers of learning and researcher as an observer (observer). CAR is done by: 1) the action planning; 2) implementation of the action; 3 ) observation; 4) acts of reflection. This activity is called a cycle, based on model cycle according Arikunto (2010: 137).

The presence of researchers in research activities in the classroom is very important. Researchers act as an instrument, meaning researchers as planning activities observers in the learning process, data collectors, analyzers and research result report

Research carried out over a cycle depends on the child's level of success achieved. Each cycle is done two meetings. Each cycle through four stages: planning, implementation, observation, and reflection. The results obtained reflection is used for the next cycle.

Researchers documented a variety of learning events that correspond to the focus issue, which noted the observation of learning outcomes assisted observation sheet that has been prepared, documenting the listening activities, the child's appearance when they came forward to explain and retell, frequently asked questions, and sing, in the form of photographs ,

The subject of this research is all kindergarten children in group B. By number of 24 children in two classes. Consist of 11 boys and 13 girls. Their average age is 5-6 years old.

This research was conducted in group B. Kindergarten is located on Betet, Kediri City.

This study will be conducted in the second semester of the school year 2015/2016 to follow lesson plans that already exist but choosing a specific theme such as theme: animals

Data to be collected Researchers in this research using the instrument as a tool used when applying a method. Instrument is prepared observation sheets that contain aspects of the child's ability to be achieved through the activities in this study include the ability of children and activities: 1) children worksheet with the method of administration tasks, 2) the method of administration tasks in the use of media manipulative "lifecycle butterfly "which includes recognize the concept of simple" life cycle of the butterfly ", mentioning the names, sort, imitating, explaining and re-telling. Sources of data in this study were teachers and children in group B and the results of cognitive ability and speaking development early childhood through the use of manipulative media "Life Cycle of the Butterfly".
Data collection techniques used in this study is the observation and documentation.

1. Method of observation (Observation)

Observation techniques used to observe the symptoms that appear in the learning process of learning to follow the child's activities.

The observations were made in conjunction with the implementation of the action from beginning to end. The observations were made using pieces of observation and assessment format assignment as a data collection instrument in learning activities through the use of manipulative media "Life Cycle of the Butterfly".

2. Method of Documentation

Documentation methods used to document data about the process of learning activities. The results of the documentation used as guidance and considerations for further learning implementation and conclusion.

The instrument used in the method of documentation

a. RKM, RKH and learning steps

b. Photo activity of students in the learning process

c. Media manipulative "life cycle of the butterfly"

d. LKA (kids worksheet).

\subsection{Technique of Data Analysis}

Analysis of the data used to process generated the data from the assessment of child development, which is symbolized by the figure of a star weight rating $(1,2,3,4)$ to test the ability of the child within the scope of cognitive skills and speaking through the use of manipulative media "Life Cycle of butterfly"

The tools used for observation capabilities and activities of children in the form of a score, while the statement is as follows:

(75-100\%): Very Good

(50-74\%): Good

(25-49\%): Enough

(0-24\%): Less

(Source: Djamarah and Zain, 2002: 121)

1. To calculate the success of the group / class used the following formula.

$$
\mathrm{P}=\frac{\Sigma \mathrm{S}}{N} \times 100 \%
$$

Notes:

$\mathrm{P} \quad$ : Percentage of votes

Is : Number of children that get a good score

$N \quad$ :Number of children that attend the learning (Source: Sudijono, 2008: 43)

1. Criteria of Success 
Data were analyzed using standard criterion of success and is said to work best when they have reached the standard percentage $\geq 75 \%$ of the average number of children were present and able to demonstrate an increase in class success in cognitive and speaking abilities.

In the use of manipulative media is average cognitive and speaking abilities of all children in the class have achieved $\geq 75 \%$. Means if the current first cycle of cognitive skills and speaking have not reached $\geq 75 \%$, then there will be a second cycle. If the second cycle has not yet reached a satisfactory outcome then, there will be three cycles and so on. The purpose of the cycles that do this is to improve the learning process that teachers or researchers in order to achieve the desired targets.

Implementation of this validation aims to collect data. The steps towards Implementation of Request Validation that willingness media experts to assist the implementation of the validation and prepare a questionnaire for the implementation of the validation. Implementation of the validation is done by submitting a questionnaire to the media expert, Prof. Dr. Punaji Setyosari, M.Pd., M.Ed.

\section{CONCLUSIONS}

1. Through the use of media manipulative "Life Cycle of Butterflies" can improve the cognitive abilities of children in kindergarten group B, particularly in indicators: 1) Mention the names of objects in the "Life Cycle of Butterflies", 2) Sorting the order of objects " Life cycle of the butterfly ", 3) Grouping objects in the" Life cycle of the butterfly "in sequence, 4) describes the return of the" Life cycle of butterflies ". Results class presentation average in the first cycle by $60 \%$ and the second cycle increased to $82 \%$, which is already included in the average score, is considered good class success.

2. Through the use of manipulative media "Life Cycle of Butterflies" can improve the speaking skills of children in kindergarten group B, particularly on indicators: 1) Listening to the explanation and answer 2-3 questions from teachers, 2) Imitate back 3-4 object "Recycling living butterfly ", 3) Linking images with words, 4) Retelling of" life Cycle of the butterfly ". Results presentation class average in the first cycle by $57 \%$ and the second cycle increased to $84 \%$, which is already included in the average score is considered good class success.

3. The use of manipulative media "Life Cycle of Butterflies" can increase the activity of children in kindergarten group B in learning cognitive skills and speaking development in the first cycle when the child who is following the process of learning activities earned an average grade of $55,6 \%$ and is included in the category enough, while in the second cycle is equal to $78,5 \%$ that fall into the category very well. So, that an increase in the activities of children in following the teaching of $23.1 \%$.

\section{ACKNOWLEDGEMENTS}

The author would like to say thank you very much for the support of various parties, among other things: 1) The family who always provide motivation and support; 2) Foundation YPLP-PT PGRI Kediri and colleagues Prodi PG-ECD UN PGRI Kediri.

\section{REFERENCES}

Arikunto, S. 2010. Prosedur Penelitian: Suatu Pendekatan Praktek. Jakarta: PT Rineka Cipta.

Dickinson, David K., dkk. (2003). "The comprehensive language approach to early literacy: The interrelationships among vocabulary, phonological sensitivity, and print knowledge among preschool-aged children". Journal of Educational Psychology.Vol 95 (3), 465-481.

Djamarah, S. Bahri dan A. Zain. (2002). Strategi Belajar Mengajar. Jakarta: PT Asdi Mahasatya

Jawati, R. ( 2013). "Peningkatan Kemampuan Kognitif Anak Melalui Permainan Ludo Geometri Di PAUD Habibul Ummi II”. Jurnal Spektrum PLS. Vol 1(1), 251-263.

Mansur. 2005. Pendidikan Anak Usia Dini dalam Islam. Yogyakarta: Pustaka Pelajar.

Rivai, A dan Sudjana N. (2010). Media Pengajaran, Bandung: Sinar Baru Algensindo

Rodgers, David L. (2005). “The Effect of Intructional Media on Learner Motivation”. Journal of Intructional Media. Vol 32( 4), 333342.

Smaldino, S.E, Russell, J.D., Henich, R., \& Molenda, M., (2005). Instructional Media and Technology for Learning. Upper Saddle Rive. NJ: Pearson Education, Inc

Sudijono, A. (2008). Pengantar Statistik Pendidikan. Jakarta: PT. Raja Grafindo Persada.

Sudjana and Ahmad. (2010). Teknologi Pengajaran. Jakarta: CV. Rajawali.

Suhartono. (2005). Pengembangan Kemampuan Berbicara Anak Usia Dini. Jakarta : Departemen Pendidikan Nasional. 
Sujiono, Y. N. (2010). Bermain Kreatif Berbasis

Kecerdasan Jamak. Jakarta: PT Indeks

Trianto. (2009). Mendesain Model Pembelajaran

Inovatif Progresif. Jakarta: Kencana Prenada. 